\title{
The Development of Web-Based Halal Information Systems to Increase Community Satisfaction: A Case Study of Participatory Ergonomics Approach in LPPOM MUI Banten
}

\author{
${ }^{1}$ Wahyu Susihono, ${ }^{2}$ Tanty Yuanita, ${ }^{3}$ Nurtanto, ${ }^{4}$ Irhamni \\ 1,2,3,4 University of Sultan Ageng Tirtayasa and LPPOM MUI Banten, Banten, Indonesia \\ ${ }^{1}$ wahyususihono@gmail.com, ${ }^{2}$ tantyyuanita@gmail.com, ${ }^{3}$ nurtanto@gmail.com, ${ }^{4} \underline{\text { irhamni@gmail.com }}$
}

\begin{tabular}{|c|c|}
\hline Article Info & |bstract \\
\hline $\begin{array}{l}\text { Article History } \\
\text { Received: July 12, } 2018 \\
\text { Accepted: September 30, } \\
2018\end{array}$ & \multirow{2}{*}{$\begin{array}{l}\text { One of the services of LPPOM MUI Banten to the community is to provide } \\
\text { information through the website, through which the community can } \\
\text { independently access various information related to halal certification. In } \\
\text { order to achieve optimum service, the website itself should meet the needs of } \\
\text { the community, and it should be communicative and informative. This } \\
\text { research aims to develop the information system of halal service based on } \\
\text { user requirement through ergonomics participatory approach and also to } \\
\text { design website by considering ergonomic display. The method used was one } \\
\text { group pretest-posttest design, while the sampling was performed using } \\
\text { systemic random sampling approach }(n=45) \text {. Result shows that the } \\
\text { information system of halal service available on the website needs to be } \\
\text { developed using ergonomic participatory approach. The development of } \\
\text { Halal Information System using participatory ergonomics approach is able } \\
\text { to increase user satisfaction by } 19.27 \% \text { (pretest average } 23.82 \pm 2.81 \text { and } \\
\text { post-test } 69.73 \pm 3.1) \text {. The formula development is also discussed. }\end{array}$} \\
\hline $\begin{array}{l}\text { Keywords } \\
\text { Information System; Halal; } \\
\text { Ergonomics Participatory; } \\
\text { Community Satisfaction }\end{array}$ & \\
\hline & \\
\hline
\end{tabular}

\section{INTRODUCTION}

Website is one of media to deliver information with its textual, visual, or even aural content which encountered as part of the user experience on website. LPPOM MUI of Banten Province has long had a website, but the existing website requires evaluation and upgrades to be more communicative and have optimal utilization. Older websites have profiles, halal, halal certificates, halal certified companies and some halal certified products, as well as some additional columns such as information on how to step or procedure to register products to be halal certified.

The development of the era, the existence of the website not only necessarily can provide complete information, but the user can also interact or communicate in two directions in accordance with the needs or desires of the user, although this communication is passive, meaning there is a complaint column or aspirations from the community. Improved quality is needed to obtain optimal website performance, the higher the quality of a web, the more users access the website (Tarigan, 2008; Barnes and Vidgen, 2001), so LPPOM MUI Banten Province needs to design a website that representative accommodate user needs, because in line with the improvement of website quality, it will affect the performance of the institution (Dewi, 2013; Mowen, 1995; Lupiyoadi and Hamdani, 2006)

Various problems that appear in the old website display among them is there is no calculation of halal certification so that the industry often experience delays in the extension of halal certification by reason of forgetting or no one reminded of a warning 
from LPPOM MUI Banten Province. Another problem is the application of halal form using hard copy, so the company must come directly to the LPPOM MUI office of Banten Province when it wants new product certification and the form of halal extension, although on one side the presence of this industry gives double benefit to the industry management because in addition to making halal form also get clinical forms free, so automatically matrix material and matrix product easily get assistance for filling. However, this condition is ineffective and is still wasteful because companies need to spend more time to visit the office. Management of companies that have implemented halal assurance system and has repeatedly filed halal certification in other words have understood the halal certification filing mechanism, then even without clinics borang, company has been able to fill matrix materials and matrix products by itself.

Website design as a means for servicing halal information system cannot be optimal for use by all parties without any process of exploring the wants and needs expected by the user, so that ergonomic participatory approach is needed as part of the decisionmaking model. The ergonomic participatory approach in ergonomic intervention can improve the quality of new product development results; this participatory approach starts from asking directly to users of some of the product alternatives used (Sutjana, et al., 1999). Participation in ergonomics provides better results when compared to policybased improvements made without the involvement of all parties as users. In general, the application of ergonomics, both total ergonomics in which there are participatory categories have been developed to solve various problems (Manuaba, 1992, 1998, 1999, 2000, 2003, 2004, 2005, 2006)

The end of the implementation of participatory ergonomics is community satisfaction, meaning, ideas or ideas from the community to develop a website-based halal service information service system with participatory ergonomic approach, able to improve the service compared with without considering the wishes of users. Improvement of this service can be measured among the level of user satisfaction (community) to open and use the website LPPOM MUI Banten Province. Satisfaction of the public or the user is one indicator of achieving the goal of each service to the community.

From several previous studies, it was reported that there is a positive influence on website design with customer or user satisfaction (Storbacka, et al., 1994; Pavlou and Chellappa, 2001). So research is needed with the aim to develop information system of halal service based on user requirement (ergonomic participatory) and designing website by considering ergonomic display. Several previous studies have reported that the more informative the website builds, the more satisfied the customers or users are in running or re-interested to visit (Jun and Chung, 2006; Girard, 2002; Chen and Wells, 1999).

\section{METHOD}

The method in this research is one group pretest-posttest Design. Sampling using Systemic Random Sampling approach $(n=45)$. Subjects in this study were 60 people who came to LPPOM MUI Banten province who previously had known and see the old website, then from 60 participants were asked again what the desire and the need for new website development. After the new website is created, then again asked how the opinion level of satisfaction of new website usage. Data on the implementation of ergonomic participatory concept is done by snowball sampling approach, meaning that every desire and the needs of the users are dug up to other needs revealed using a free questionnaire. 


\section{RESULT}

The ergonomic participatory concept is to solve problems based on inputs, suggestions from users in order to achieve an increase in breadth, comfort and service to realize a better quality of work life. On the issue of website development, which became the user is the industrial society processed food products, beverages and drugs and cosmetics. This community is the user of the information system built by LPPOM MUI Banten province. When all the needs desired by the community for halal certification management are well provisioned in the website, the satisfaction of the service provided by the LPPOM MUI Banten province becomes higher, but when the information system service on the website does not accommodate the needs and wishes of the community for the use of halal service, then it is possible industry satisfaction industry will decrease or not maximal.

Modules or display on the LPPOM MUI website of the old Banten Province, which is before 2016 only in the form of Profile, Certificate Number, Company Name and Product already certified halal as well as some other views such as news, process information or certification flow and activities conducted by auditor and website others who support the activities of LPPOM MUI Banten Province.

Views on the LPPOM MUI website of Banten province before 2016 need to be refined and developed in accordance with the needs and wishes of the user community. The wishes of the user community are captured using ergonomic participatory methods involving the wishes and expectations of the users in this industry society. Hope result from developmentof this website is in addition to the main function of the development of information systems based website halal services can also improving satisfaction with the services provided by LPPOM MUI Banten Province.

Participation means everyone should be involved from the beginning to the end of the program. Some of those involved are workers in the steel printing station, Production Manager, General Manager to determine the priority issues to be resolved and consideration of the application of the TTG to be designed. Participatory approaches to ergonomic interventions can improve the quality of new product development results; this participatory approach starts from asking directly to users of some of the product alternatives used (Sutjana, et al., 1999).

The ergonomic participatory stages are as follows: a) Management or management and representatives of the industry as website users LPPOM MUI Banten Province Sitting together, b) Unveiling problems with Role Play approach, then the results are laid out in Ishikawa diagram, c) Determine the priority of the problem and seek some alternative solutions, generally using the NGT method), then some positive statements $(+)$ are changed into negative statements $(-)$, d) Create an action plan using the $5 \mathrm{w} 2 \mathrm{H}$ approach, e) Implement previous actions all activities have been poured into the Gant Chart , f) Conduct evaluation of results by sitting together from policy makers or website makers with the community in this case as users or users of the website, g) In order to avoid recurrence problems and periodically to be evaluated, standard Operating Procedure (SOP ), h) For all users and auditors to be able to mem take advantage of the website optimally, then made Socialization of SOPs that have been made, in general website socialization conducted simultaneously with training activities of halal assurance system ( $\mathrm{SJH})$. The results of the development of information system of website-based halal services obtained by the results of participatory ergonomics are as follows: 


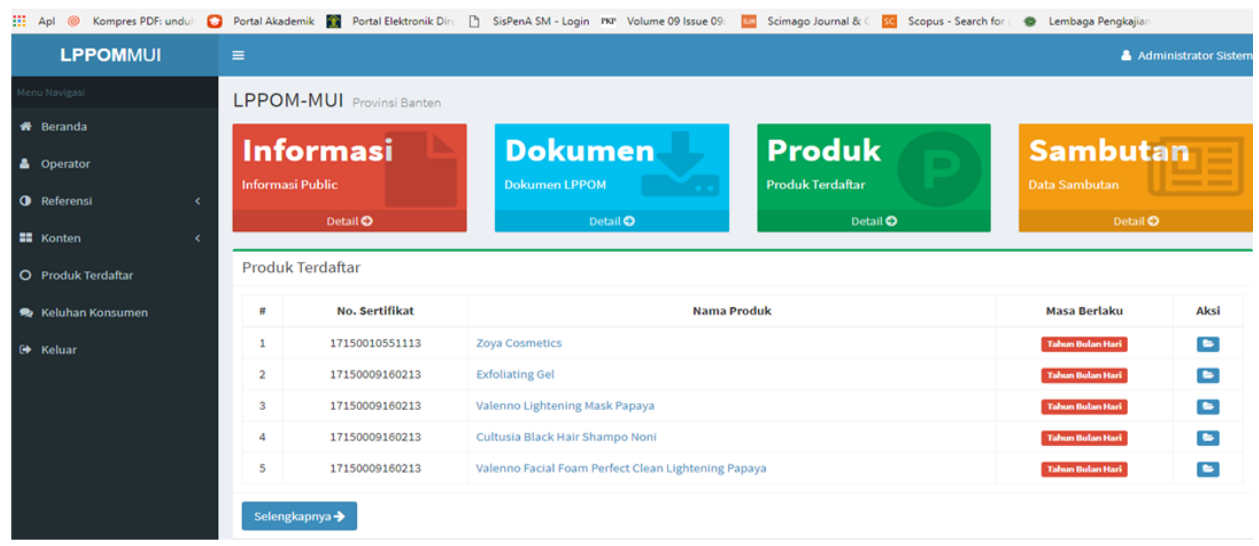

Figure 1: Administrator System Menu

Based on Figure 1, the system administrator menu is more complete than the menu on the previous website display. The fundamental difference is the addition of "Greeting, Documents, and Consumer Complaints". All three of these content on the previous website does not exist so the user no two-way communication passively. The validity period of the product has also been translated into "Year-Months" making it easier for halal-certified industries to remind and apply for halal certification per three months before the certificate expires.

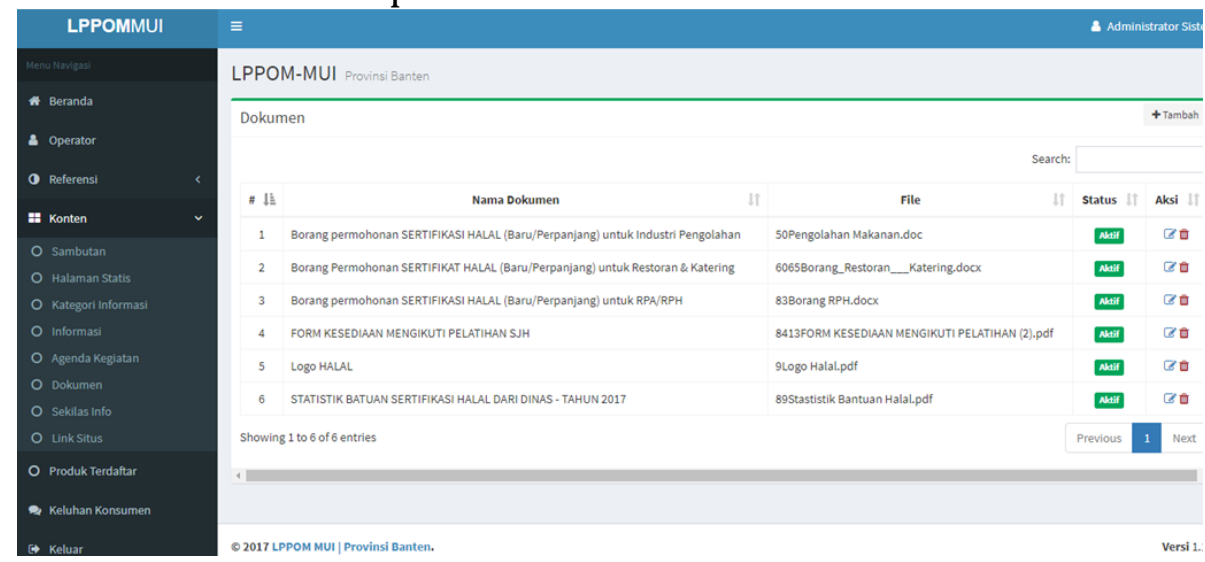

Figure 2: Navigation Menu

Based on Figure 2, the navigation menu shows a more detailed content, namely a) Greeting; it includes the Director's remarks, remarks from each field head, b) Static Pages; the page which includes several sub menus displayed at the beginning of the website, c) Category of information consisting of information announcements, as well as information that is news, d) Event agenda of content agenda that will appear on the right side of the website and will form a link when clicked , e) Documents; contains files that can be used for uploading documents which the user can download independently f) info overview; will appear becomerunning text, g) Site Links; used for the column of the circle with some sites still relevant to the institution, h) Registered products; used for the upload of halal certified products including halal certificate number, company name, product name and date of certificate, i) complaints of customers; columns used to capture and accommodate complaints from consume, replies to complaints are sent via email or sms. Changes appear and menu on the new website can be seen as follows: 


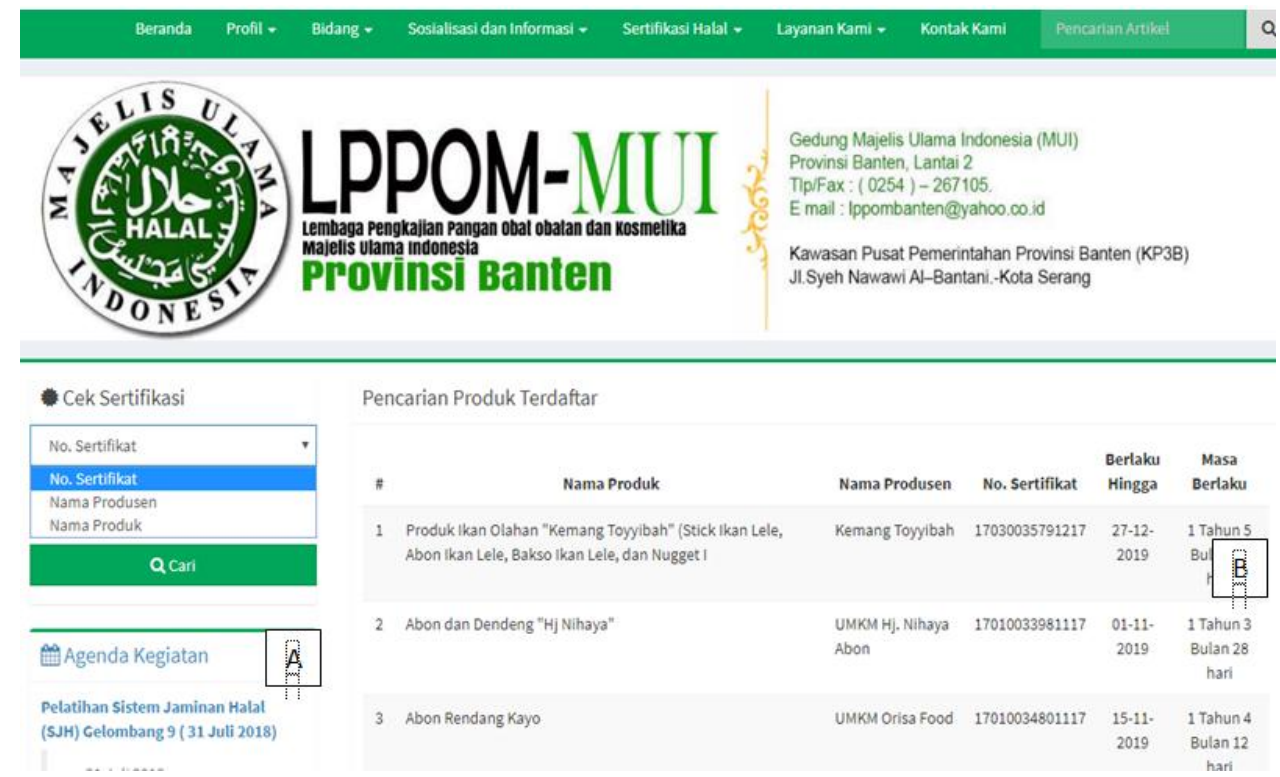

Figure 3: Views of new website--3a; Search halal product columns, 3b; halal certificate validity period column

Based on Figure no 3a, the search field of certificate number, company name and product are already halal certified. Companies or communities can choose one of the notifications to find products that have been certified by LPPOM MUI Banten province. This column makes it easy to find products that are the subject of search. Companies that have achieved halal certification can monitor the halal certificate's expiry date as shown in Figure 3b, the halal certificate is valid for 2 years, in this new website view, it will automatically be counted backwards. Remuneration of halal certificate of each company is done in 3 stages, when the validity of halal certificate has reached 3 months, 2 months and 1 month before halal certificate expired. Notifications will go directly to the company email and also through sms into the number that has been registered. So because of the many companies in the sms on each period, the application on this website is also equipped with syncing facilities sms gateway and email service facility.

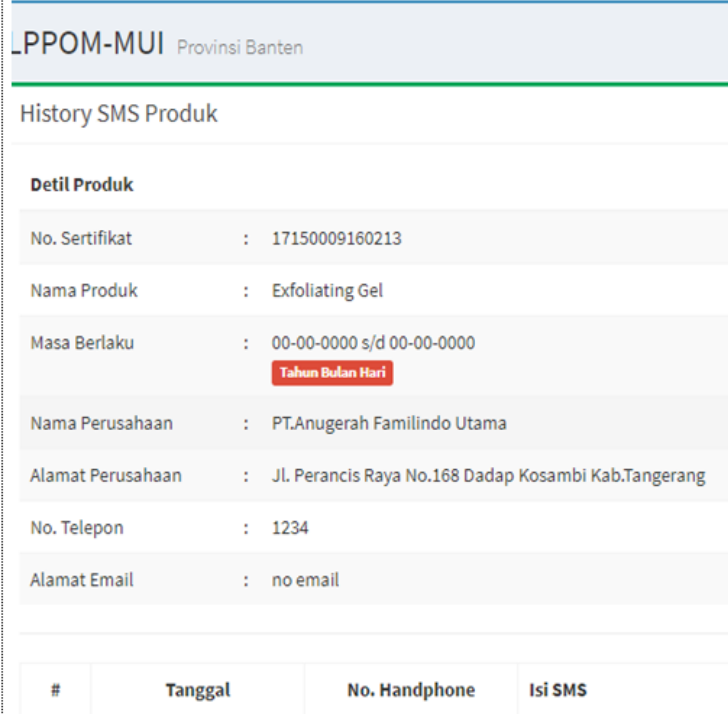

Figure 4: SMS history from user 


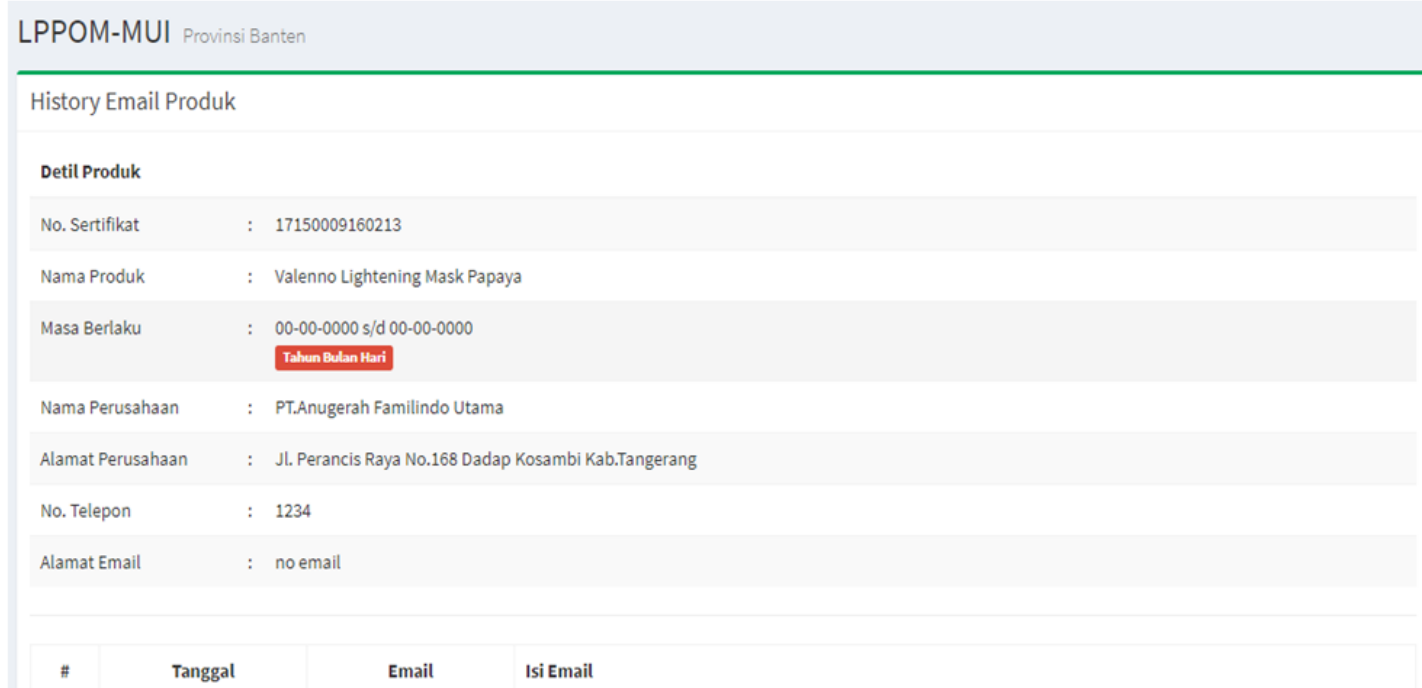

Figure5: Email history from user

Based on figures 4 and 5, we can be sure that every incoming email and sms will be recorded, historical communication 2 parties (operator in LPPOM MUI Banten Province and industry side). The email and sms history of the user will facilitate quick and precise response. In general, this column is used for companies that will add products or materials in each period, because new products or materials must be reported to LPPOM MUI Banten Province as part of Halal Assurance SystemManual.

Other facilities that can be designed from ergonomic participatory results are the addition of the download column of various halal application forms and Halal Assurance System $(\mathrm{SJH})$ training as well as the addition of an open service complaint column.

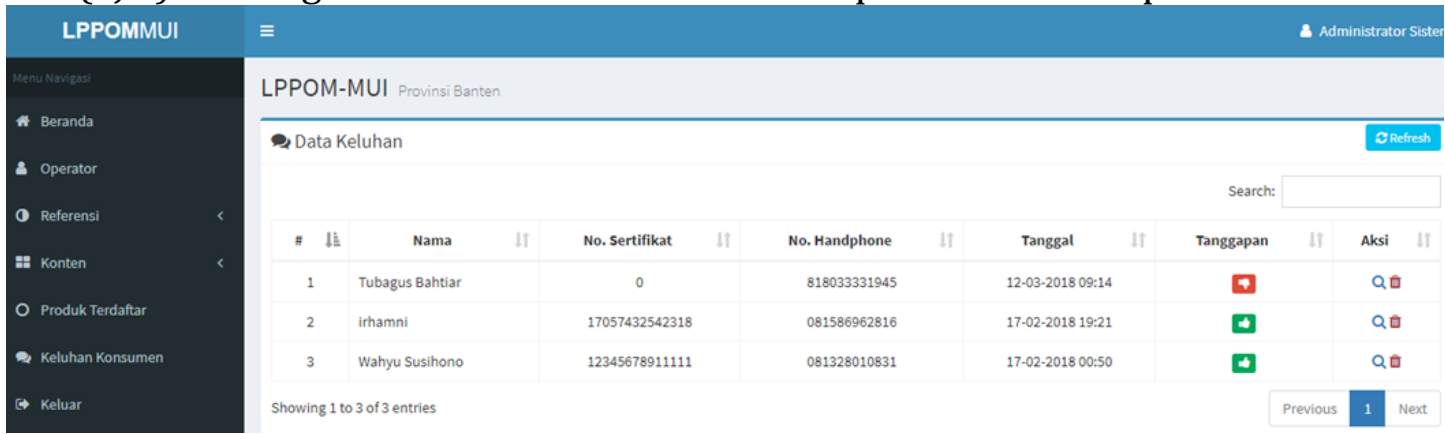

Figure 6: Customer Complaints Data

Based on the Figure 6, customer complaints data when read and reply will have green notification, but if there has been no response from the operator it will remain red, it aims to facilitate the grouping of emails that have been replied, with emails that are still waiting for replies. In filling out the customer complaints column, the user only needs to include the certificate number and mobile phone number, these two identities will accelerate the complaint process done by the company. If necessary, the website operator will cross check through the phone as a follow up of the complaints already submitted to the board of LPPOM MUI of Banten Province.

Other website changes include a change in the background color of the website view to green and yellow which was originally dominant green color only, so this new website is expected to be user friendly and can be opened through android facilities.

One's satisfaction can be seen from several indicators, namely the optimization of activities, skills, authority, creativity, independence, values, recognition, responsibility, security, social service, social status (Syamsi, 2004). When using the website in accordance with the wishes and needs, then there is satisfaction (Alpar, 2001), let alone 
some ideas and ideas used for improvement efforts and development of new website look. Assessment of satisfaction is measured by asking some of the sides of which are: website display, font size, large needs that have been accommodated, speed and accuracy of service, ease of access, news updates, ease and accuracy of halal product search, the speed of response from the operator.

Website design has a significant effect on customer satisfaction, the results of this study with other studies that have been done before (Ki-Han and Jae-Ik, 2009; Lohse and Spiller, 1998; Walczuch, et al., 2001). This suggests an attractive site design will have an impact on the desire to continue to visit.

If you are informed by changes in user satisfaction after using the new website changes, Development of Information Systems Halal services can improve user satisfaction (pretest average $23.82 \pm 2.81$ and posttest $69.73 \pm 3.1$ ) or increase user satisfaction by $19.27 \%$. This satisfaction will continue to increase in line with the increase of service to the user. The results of the study using ergonomic participant conceptual can increase user satisfaction, in line with previous research (Susihono, 2017).

\section{CONCLUTION}

Halal service information system through website should be developed through ergonomic participatory approach that can be obtained through following formula: (a) addition of halal certificate validity period (in days); (b) addition of sms gateway facility and email service facility for remainder validity of halal certificate; (c) addition of downloadable column of various halal application forms and training of Halal Assurance System (SJH); (d) addition of customer complaints column; and (e) change of the color of the background of the website to be identical colors of green and yellow user friendly or easy in operation and can be opened through android facilities.

Development of Information Systems Halal services can improve user satisfaction (pretest average $23.82 \pm 2.81$ and posttest $69.73 \pm 3.1$ ) or increase user satisfaction by $19.27 \%$.

\section{REFRENCE}

[1] Aljukhadar, M. Senecal S. 2009. How the Website Usability Elements Impact Performance: Americas Conference on Information Systems. p18

[2] Alpar, P. 2001. Satisfaction with a Web site: Its measurement, factors and correlates, Working Paper 99(1), Philipps University Marburg Institution Wirtschaftsinformatik

[3] Chen, Q. Wells, W.D. 1999. Attitude towards the site. Journal of Advertising Research 39 (Sept /Oct).p27-47

[4] Dewi. P, Budi. P, Sumiyana. 2013. Customer Satisfaction Review Website Universitas Airlangga. Master Management. Higher Education Gadjah Mada University

[5] Girard, T. Silverblatt, R. and Korgaonkar, P. 2002. Influence of product class on preference for shopping on the Internet. Journal of Computer-Mediated Communication 8(1).http://www.ascusc.org/jcmc/vol8/issue1/girared.html

[6] Green, D.T. Pearson, J. M. 2004. Confirmatory Factor Analysis of Two Web SiteUsability Instruments. In Proceeding of the Third Annual Workshop on HCI Research. pp10- 11

[7] Jun, S.E. Chung, K.H. 2006. A study on the factors of Internet shopping site affecting customer's e-satisfaction, e-loyalty, and repurchasing intention. Journal of Internet Electronic Research 6(2). pp. 133-158. 
[8] Ki-Han, Chung. Jae-Ik, S. 2009. The Relationship between Site Characteristics, Relationship Quality, and Word of Mouth. International Journal of Business and Information. pp. 137-160

[9] Lohse, G. L. Spiller, P. 1998. Electronic shopping: The effect of customer interfaces on traffic and sales. Communications of the ACM, .41(7). pp. 81-87.

[10] Lupiyoadi, R. Hamdani, A. 2006. Marketing Management Services. Jakarta: Salemba Empat.

[11] Manuaba, A. 1992. Implementation of ergonomics to improve the quality of human resources and productivity: The material of the K3 Seminar with the theme through our K3 culture we improve the quality of human resources. Ergonomics Bonds. Vol 1. Denpasar. Ergonomic Physiology Study Program. Universitas Udayana

[12] Manuaba, A. 1998. Ergonomics and Occupational Health and Fire Prevention. Ergonomics Bonds. Vol. 1. Denpasar: Graduate Program. Universitas Udayana.

[13] Manuaba, A. 1999. Implementation of Ergonomic Participation in Improving Industrial Performance. (Papers). Presented at the National Seminar on Ergonomics, Revaluation of Ergonomic Implementation in Improving Industrial Performance. Surabaya 23 November.

[14] Manuaba, A. 2000. Ergonomics Improving Labor and Company Performance. In : Hermansyah. Editor. Proceeding Simposium and the Ergonomic Exhibition Indonesia 2000. Bandung: ITB Press.

[15] Manuaba, A. 2003. Optimization of Ergonomic and Sports Physiology Application in Order to Increase Productivity of Labor and Achievement of Athletes. (Papers). Presented at the National Seminar on Ergonomics and Sport at Semarang State University. Semarang 12 April.

[16] Manuaba, A. 2004. Holistic Ergonomics Approach A Must In Automation To Achieve Work Process And Products That Humane, Competitive And Sustainable. Paper. Presented at the National Seminar on Ergonomics, Ergonomic Applications in Industry, Industrial Engineering Communication Forum Yogyakarta and Indonesian Ergonomics Association. Yogyakarta 27 March.

[17] Manuaba, A. 2005. Total Ergonomic Enhancing Productivity, Product Quality and Customer Satisfaction. Paper. Presented at National Seminar II Quality Improvement Manufacturing System and Services, Industrial Engineering Communication Forum. Yogyakarta.

[18] Manuaba, A. 2006. A Total Approach In Ergonomics Is A Must To Attain Humane, Competitive And Sustainable Work System And Products. In Adiatmika and Putra, D.W. editors. Proceeding Ergo Future 2006: International Symposium On Past, Present And Future Ergonomics, Occupational Safety and Health. 28 - 30th August. Denpasar: Department of Physiology Udayana University - School of Medicine. p. 16.

[19] Mowen, C. 1995. Consumer behavior, Prentice Hall, Inc, Englewood Cliffs. New Jersey. International Edition.

[20] Pavlou, P.A. Chellappa, R. 2001. The role of perceived privacy and perceived security in the development of trust in electronic commerce. Working Paper. Marshall School of Business. University of Southern California. Los Angeles

[21] Storbacka, K. Strandvik, T. Gronroos, C. 1994. Managing customer relationships for profit: The dynamics of relationship quality. International Journal of Service Industry Management 5(5). pp. 21-38.

[22] Susihono, W. Adiatmika. Parwata, Y. Sudiarsa. 2017. Implementation of Total Ergonomics Approach through Multidisciplinary Sciences for the Improvement of Workers' Health Quality: Literature Review Doctoral Dissertation Udayana Bali- 
Indonesia. Journal of Global Pharma Technology (Indexing Scopus-Q4); 09(9):252256

[23] Sutjana, I.D.P. Adiputra, N. Manuaba, A. Neill, D.0. 1999. Improvement of Sickle Quality through Ergonomic Participatory Approach at Batunya Village Tabanan Regency. Journal of Occupational Health (JOH). 41: 131-135

[24] Syamsi, I. 2004. Efficiency, System, and Work Procedures. Revised Edition. Earth Script. Jakarta.

[25] Walczuch, R. J. Seelen, H. Lundgren. 2001. Psychological Determinants for Consumer Trust in E-Retailing. Proceedings of the Research Symposium on Emerging Electronic Markets (RSEEM). Maastricht. The Netherlands 